\title{
UROTAC-Ectopia renal cruzada
}

A. Ojea Calvo, M. Otero García, F. Domínguez Freire, A. Alonso Rodrigo, B. Rodríguez Iglesias, J. Benavente Delgado, JM Barros Rodríguez

Hospital Universitario Xeral-Cies. Vigo. Pontevedra

Actas Urol Esp 2005; 29 (5): 534

T as nuevas técnicas de exploración urológica Uson cómodas, inocuas, rápidas y seguras en los diagnósticos, facilitando al urólogo imágenes virtuales de la anatomía muy útiles a la hora de ejecutar la cirugía.

En este sentido, el UROTAC ya ha sustituido a la Urografía Intravenosa como técnica de exploración urológica. En el UROTAC de las imágenes se puede apreciar, con una técnica de baja dosis (120 Kv y 100 más) todos los elementos de la vía excretora y su trayecto, en una ectopia cruzada con sínfisis.

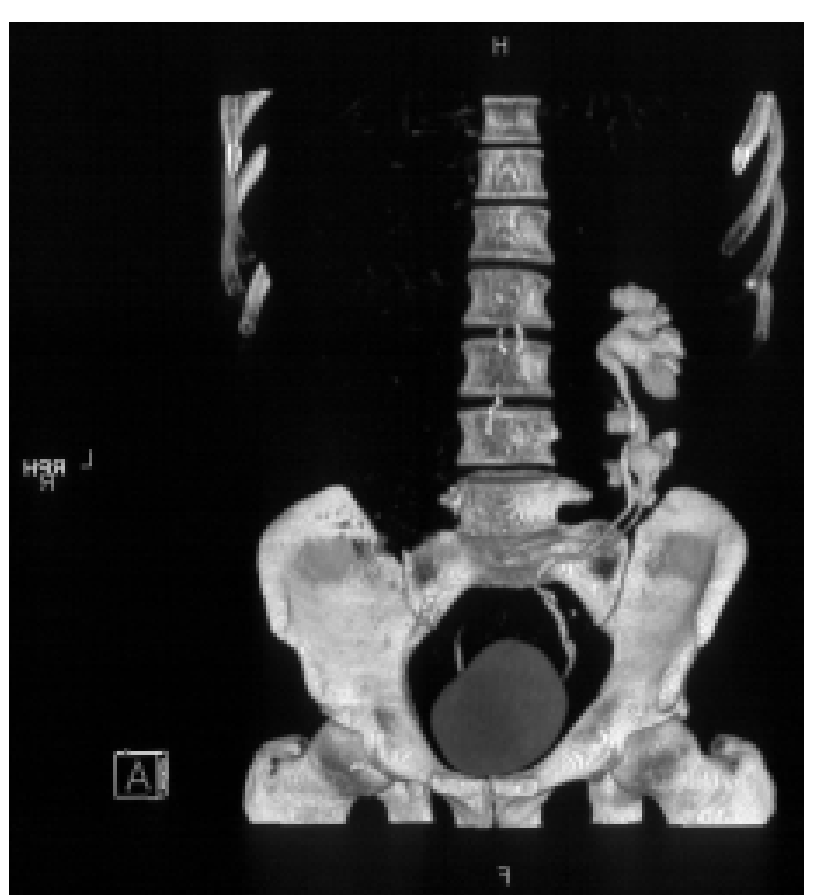

